\title{
A CONSTRUÇÃO DE UMA METODOLOGIA PARA O LETRAMENTO DIGITAL
}

\section{BUILDING A METHODOLOGY FOR DIGITAL LITERACY}

Flávia Girardo Botelho Borges ${ }^{147^{*}}$

RESUMO: Este artigo propóe a descriçăo de uma metodologia para a construçấo do letramento digital, entre crianças ainda năo alfabetizadas formalmente. Para atender a esse objetivo, elaborou-se um conjunto de doze testes dentro de seis domínios do letramento digital (do ambiente de Informática, das habilidades icônicas, da conectividade, da realizaçâo de múltiplas tarefas, do letramento alfabético e digital e da comunicaçăo na internet), considerados como representativos das habilidades linguístico-cognitivas envolvidas na aquisiçâo do letramento digital. À elaboraçâo dos testes, subjaz a construçáo de um referencial teórico a respeito dos estudos dos letramentos e o entendimento de que as habilidades linguístico-cognitivas envolvidas na construçáo do letramento digital entrelaçam-se umas às outras, em uma perspectiva de continuum, além de uma contextualizaçâo do momento sócio-histórico cultural que atravessamos neste momento. A metodologia aqui descrita pressupóe uma pesquisa de caráter longitudinal, quantitativa e qualitativa, que tomará corpo no espaço escolar, tendo como sujeitos crianças de 5 a 6 anos.

Palavras-chave: Letramento Digital; Metodologia de pesquisa; Habilidades Linguísticocognitivas; Linguística Aplicada.

Abstract: This paper tentatively describes a methodology for digital literacy building in preliterate children. The author developed a set of 12 tests in six digital literacy domains: digital environment, iconic abilities, connectivity, multitasking, alphabetic and digital literacies and online communication. The author considers these domains as hallmarks of linguistic-cognitive abilities involved in digital literacy acquisition. Underlying the development of these tests, there is the building of a theoretical framework regarding literacy studies. Also, there is an understanding that linguisticcognitive abilities involved in digital literacy are intertwined. These are inside a perspective of continuum and beyond establishing a context for the current sociohistorical and cultural we are going through. The methodology herein assumes a study of a longitudinal, both quantitative and qualitative, nature which takes shape in a school environment with 5-6 year-old children.

Keywords: Digital literacy; research methodology; linguistic-cognitive abilities; applied linguistics.

147 Universidade Federal de Mato Grosso, Cuiabá. Doutora em Letras - Linguística pela Universidade Federal de Pernambuco. Professora Adjunta do Departamento de Letras, da Universidade Federal de Mato Grosso, Cuiabá (MT). E-mail: flavia2b@gmail 


\section{INTRODUÇÃO}

O ponto de partida para este estudo foram nossas vivências particulares ao observarmos que, da mesma forma que as crianças já dominam alguns conhecimentos a respeito das letras antes de se alfabetizarem (hipótese amplamente explorada por Ferreiro e Teberosky, 1999), elas também podem ter, hipoteticamente, algum conhecimento a respeito do mundo digital, antes mesmo de atravessarem os portóes da escola, já que as novas ferramentas tecnológicas, como computador, smartphones, ipods, tablets, estăo cada vez mais inseridas nas práticas de atividades cotidianas. Por este motivo, Xavier (2007, p. 133) alega que "alguns estudiosos começam a falar no surgimento de um novo tipo, paradigma ou modalidade de letramento, a que têm chamado de letramento digital".

É fonte comum de notícias na mídia televisa e impressa o fato de crianças pequenas já cultivarem o hábito de se sentar em frente a um computador, clicar com o mouse, se engajar em jogos digitais interativos, com sons, movimento, mensagens hipertextuais, navegar em sites e, em alguns casos, até manter páginas pessoais em sites de relacionamento, com auxílio de adultos. Todavia, elas ainda năo foram formalmente alfabetizadas, isto é, ainda năo se apropriaram das relaçōes do sistema alfabético, mas já realizam atividades com ferramentas digitais com base em outras habilidades linguístico-cognitivas.

Dito isso, muitas questōes a este respeito surgem, como: o que as crianças fazem quando usam o computador? Como navegam pela internet? Elas realmente sabem o que é a internet? Como elas aprendem a lidar com os equipamentos eletrônicos? Com este desafio posto e tantas questóes em aberto, começamos a pensar numa metodologia para investigar esse fenômeno, o letramento digital.

Assim, buscamos apoio em teorias da Linguística e em outras áreas do conhecimento, para uma melhor compreensáo tanto deste momento sócio-histórico-cultural quanto das diversas práticas linguísticas e atividades cognitivas envolvidas neste processo. Entendemos que uma pesquisa se limita por vários fatores: tema, objetivo, tempo, custo, espaço, sujeitos, instrumental, entre outros. As fronteiras de um estudo se alargam e se contraem na medida em que se realiza o estudo. $O$ esboço das fronteiras deste estudo pretende traçar um desenho do que pode se realizar em campo, entretanto, como um esboço, está em permanente construçáo, desconstruçáo e reconstruçáo, pois entendemos que a pesquisa se atualiza a cada momento de sua vivência.

Em se tratando de letramento digital, essa atualizaçăo faz-se urgente, visto que temos novos aplicativos, equipamentos, gêneros textuais a cada nova versăo do sistema operacional. Assim, as rotas metodológicas indicam um rumo, um norte, todavia, o percurso para se alcançá-lo é costurado por incertezas, erros, acertos e descobertas. Este artigo descreve o processo de construçấo de uma metodologia de pesquisa voltada ao letramento digital.

\section{A PERSPECTIVA DO LETRAMENTO: TEORIA E PRÁTICA}

A perspectiva do letramento incorpora à vida social dos sujeitos a necessidade de dominar as práticas de leitura e escrita com o risco de, năo as dominando, encontrar 
dificuldade de identificaçăo e integraçaáo àquela comunidade, sociedade. Goody (2006, p. 17) aponta que o domínio da linguagem, da língua, atua na vida do indivíduo como "a organizaçấo homeostática do corpo humano, por meio da qual ele tenta manter sua condiçấo de vida presente", sendo impossível permanecer num grupo sem dominar os usos de linguagem pertencentes ao mesmo.

Na mesma perspectiva, Bazerman (2007, p. 21) afirma que "o letramento é parte constitutiva de uma matriz de formaçóes culturais e sociais complexas da sociedade moderna com a qual respondemos a instituiçôes, crenças, grupos de pessoas localizados longe de nossa vida diária" e que nos tornaria parte dessa sociedade. Concordamos com Buzato, quando este afirma que adquirir um certo letramento:

É participar de um conjunto de práticas sociais nas quais significados e sentidos de certos conteúdos codificados culturalmente (tradicionalmente, mas năo exclusivamente, textos escritos) săo gerados, disputados, negociados e transformados (BUZATO, 2010, p, 53).

Esta aquisiçâo tem sido realizada pelas atividades da leitura e da escrita, na escola, na mídia e na sociedade. Todavia, na sociedade pós-moderna, vivemos uma época integrada pela tecnologia, e para estar e sentir-se inserido nas práticas de leitura e escrita atuais, é preciso dominar mais que a leitura e a escrita convencionais, é preciso letrar-se digitalmente.

O cenário da atualidade é resultado da mudança de paradigma exercida pela cibercultura, definida, segundo Lemos (2003, p. 11), como "a forma sociocultural que emerge da relaçâo simbiótica entre a sociedade, a cultura e as novas tecnologias de base microeletrônica que surgiram com a convergência das telecomunicaçôes com a informática na década de 70" e que modificou as formas de agir, pensar, comunicar-se e se relacionar. Entre essas formas socioculturais, a Internet alcançou níveis de inserçâo talvez inesperados. Segundo dados do IBOPE, a Internet já é uma realidade na vida de mais de 82 milhóes de brasileiros, depois de quase 20 anos de existência.

Entretanto, se considerarmos que acesso à Internet pode ser realizado por outros meios, além do computador, como por aparelhos celulares, o crescimento foi ainda maior, sendo que em 2010, 94 milhōes de pessoas declararam possuir este aparelho. E, dentre a parcela jovem da sociedade de 10 a 14 anos, 29\% deste total têm telefones celulares no Brasil.

A abrangência da cibercultura na vida cotidiana é inegável, de forma que hoje há a necessidade de outro letramento, além daquele originalmente ofertado pela escola, o letramento digital, que precisa ser investigado e explorado. Neste ínterim, Xavier explica que o letramento digital:

Considera a necessidade de os indivíduos dominarem um conjunto de informaçóes e habilidades mentais que devem ser trabalhadas com urgência pelas instituiçóes de ensino, a fim de capacitar o mais rápido possível os alunos a viverem como verdadeiros cidadăos neste novo milênio cada vez mais cercado por máquinas eletrônicas e digitais (XAVIER, 2007, p. 133).

Neste sentido, estudiosos holandeses, Veen e Vrakking (2009), defendem que a aprendizagem das crianças da era digital se realiza de maneira muito diferente daquela conhecida anteriormente. Para os autores (VEEN; VRAKKING, 2009, p. 29), "a geraçâo 
da rede difere de qualquer outra do passado porque cresceu em uma era digital".

Anteriormente ao processo escolar da alfabetizaçăo, as crianças, muitas vezes, já realizam tentativas de leitura. Entretanto, estes atos provavelmente náo se concretizam a partir do verbal, e sim do náo verbal ou do icônico, isto é, das imagens, cores, marcas como negrito, sublinhado, sons, movimento. Com o intenso contato com o mundo digital, as crianças parecem entender alguns processos próprios das atividades de leitura e de escrita e podem apresentar desenvolvimento de algumas habilidades fundamentais para a aquisiçāo da leitura e da escrita, para o letramento.

Como prática cotidiana da cultura digital, essas crianças podem desenvolver, a partir dos recursos do mundo digital, habilidades linguístico-cognitivas, assim denominadas já que para sua realizaçăo necessitam ativar a linguagem e, consequentemente, a cogniçâo. Săo processos como a atençâo, a memória, a percepçâo, a realizaçăo de inferência, entre outras, necessários para o acesso a páginas da rede, leitura de hipertexto, entendimento do funcionamento de links, participaçăo em jogos digitais, acesso a sites, participaçăo em redes sociais, entre outras atividades com as ferramentas digitais.

Em relaçáo aos novos saberes proporcionados pela cibercultura, Lévy aponta que:

O ciberespaço suporta tecnologias intelectuais que amplificam, exteriorizam e modificam numerosas funçóes cognitivas humanas: memória (banco de dados, hiperdocumentos, arquivos digitais de todos os tipos), imaginaçấo (simulaçóes), percepçăo (sensores digitais, telepresença, realidades virtuais), raciocínios (inteligência artificial, modelizaçăo de fenômenos complexos) (LÉVY, 1999, p. 157).

A exposiçăo das crianças de hoje às tecnologias intelectuais que viabilizam a cibercultura, segundo Lévy, parecem levá-las a construir hipóteses sobre a atividade de ler e de escrever. Apesar de ainda năo serem alfabetizadas, isto é, năo dominarem o sistema alfabético, elas conseguem encontrar soluçōes para obter êxito em suas necessidades comunicaçăo e de diversăo por meio do computador, celular ou outro equipamento digital.

Dizendo de outra maneira, o contato e a prática frequentes de açôes que demandam o uso de diferentes linguagens para consignar momentos de interaçáo mediada por computador estăo impulsionando as crianças a desenvolver estratégias de natureza linguístico-cognitivas que estamos chamando de letramento digital. Sobre essa questăo, Lévy (1999, p. 157) explica que as atividades digitais "favorecem modos inovadores de acesso à informaçăo e novos estilos de raciocínio e conhecimento, ainda a possibilidade compartilhamento entre numerosos indivíduos".

Na mesma direçấo, Xavier indica que os sujeitos que praticam atividades digitais săo capazes de, entre outras coisas,

Apreender, gerenciar e compartilhar os novos conhecimentos aprendidos com os parceiros de suas comunidades virtuais; checar online a veracidade das afirmaçóes apresentadas e refutar com base em dados disponíveis na rede, a fim de exercitar a crítica a posicionamentos e náo simplesmente acolher de tudo o que se diz na Internet como verdades incontestáveis. Explorar e contemplar as formas de arquitetura escolhida para apresentar as ideias materializadas em discursos hipertextuais, os quais se valem tanto do sistema semiótico verbal quanto do visual e do sonoro como estratégia multissemiótica para se fazer entender entre as inúmeras páginas indexadas diariamente à grande rede (XAVIER, 2007, p. 8).

Para o autor, o exercício diário de tais atividades (apreender, gerenciar e 
compartilhar novos conhecimentos, checar afirmaçôes online etc.) săo atividades que exigem da criança um considerável esforço mental para realizá-las. Săo desafios aos quais as crianças inconsciente e voluntariamente săo submetidas de modo que precisam enfrentá-los, caso queira continuar a brincar, a se informar, a se comunicar, enfim, a interagir por meio de uma potente máquina que conecta pessoas a distância e fornece-lhes imagens, sons e textos.

Por isso, pareceu-nos interessante e razoável trabalhar com a possibilidade de que a prática de atividades digitais contribuir diretamente para o desenvolvimento de habilidades linguístico-cognitivas, que poderâo auxiliar no processo de Letramento. 0 tema "letramento digital" vem sendo explorado no campo de pesquisas da Linguística, da Educaçấo, da Psicologia e de outras áreas, dada a novidade que o acompanha. Desafiada por essa espontaneidade e pelo caminho inexplorado, propusemo-nos a investigar a construçấo e as qualidades distintivas fundamentais do que seja este fenômeno, com crianças muito pequenas, todavia precisávamos de uma metodologia.

\section{LETRAMENTO DIGITAL NA PRÁTICA}

Partimos, entăo, à pesquisa sobre estudos anteriores realizados com crianças ou adolescentes. Em 2011, Xavier havia desenvolvido um estudo, de cunho exploratório longitudinal, com 25 sujeitos, 9 a 14 anos de idade, matriculados em uma escola particular de Recife-PE, sobre o letramento digital. A pesquisa acompanhou, por oito meses, as atividades com ferramentas digitais realizadas por esses sujeitos na escola, individual e coletivamente. Para coleta dos dados, ele havia usado a captaçăo de imagens em vídeo das açôes dos sujeitos utilizando computadores no laboratório de informática da escola, bem como havia aplicado, por e-mail, um questionário socioeconômico para levantar informaçōes sobre condiçôes financeiras e hábitos tecnológicos dos informantes de sua investigaçăo.

Durante as filmagens, os sujeitos eram questionados a respeito de como, quando, onde e por que utilizavam computadores, programas, telefone celular e jogos eletrônicos. Os resultados desse estudo mostraram que estes sujeitos tinham acesso a computadores conectados à internet desde muito cedo, manuseavam as ferramentas de comunicaçáo a distância como e-mail e programas de mensagens instantâneas com frequência, passavam, em média, mais de duas horas conectados por dia, com tendência a ampliar esse tempo à medida em que a idade aumentava. A pesquisa mostrou que, entre os adolescentes investigados, a maioria deles apresentava um bom domínio das novas mídias digitais de informaçăo e comunicaçăo, pois, como disse o autor: "nasceram imersos no modus vivendi digitale" (XAVIER, 2011, p. 9).

Na esteira desse estudo, começamos a delinear a proposta metodológica da nossa investigaçăo. A intençăo era acompanhar as atividades realizadas com o computador por crianças com idade entre cinco e seis, ainda năo alfabetizadas formalmente. Entretanto, como desenvolver atividades com crianças tăo pequenas? O que elas já saberiam fazer? Estariam interessadas em utilizar um computador? Eram algumas de nossas indagaçōes e incertezas.

No entanto, havia partes do terreno seguras. Alguns pressupostos já estavam delineados, o estudo deveria se caracterizar como uma pesquisa de campo do tipo longitudinal, 
de caráter quanti-qualitativo, o que demandava a constituiçăo de um grupo de sujeitos, com características afins, resguardadas suas singularidades e aprovaçăo pelo comitê de ética em pesquisa. $O$ estudo deveria acontecer em uma escola com disponibilidade para nos receber, pois entendemos que qualquer pesquisa altera, de alguma maneira, o cotidiano escolar e, como se tratava de crianças pequenas, a rotina delas e da própria escola requeriam cuidados especiais por parte dos pesquisadores, professores e gestores.

As escolas foram escolhidas considerando-se os índices fornecidos pelos sistemas oficiais de avaliaçáo educacional, como a Prova Brasil, a existência de laboratório de informática em boas condiçôes de uso, além de outros critérios que garantiam o máximo de isonomia intelectual e biológica entre os sujeitos matriculados em escolas pública e privada, tais como o estado nutricional adequado dos sujeitos informantes.

Dentro deste quadro, selecionamos duas escolas: uma da rede pública e outra da rede privada de ensino, ambas da Regiăo Metropolitana de Recife, Pernambuco, ambas com bons resultados nas avaliaçóes. Mantendo em mente que intencionávamos descrever o processo de construçâo do letramento digital, em crianças pequenas, tornou-se interessante criar critérios de seleçâo para os sujeitos. Assim, a ideia inicial do estudo era criar e realizar testes sobre letramento digital com 30 crianças de cinco anos de idade, na fase pré-silábica de alfabetizaçăo, que seriam divididas em dois grupos de estudo, um para cada espaço da pesquisa. Os grupos seriam filmados realizando atividades pedagógicas no laboratório de informática das escolas.

\section{FASES DA AQUISIÇÃO DA ESCRITA}

Para que năo houvesse disparidades entre os grupos de crianças, escolhemos adotar fases de aquisiçăo da escrita, segundo Ferreiro e Teberosky (1985), fase pré-silábica, fase silábica, fase silábico-alfabética e fase alfabética, para a seleçăo do grupo de sujeitos. Como forma de equiparar o processo de construçăo do sistema de notaçăo alfabético, escolhemos categorizar as crianças de acordo com os postulados dessas educadoras.

Neste tocante, os sujeitos selecionados foram categorizados na fase pré-silábica, o que correspondia que entendiam a escrita como uma forma de representaçăo, já utilizavam algumas letras, realizavam garatujas, mas ainda năo compreendiam a escrita como representaçấo da fala, e relacionavam o tamanho da palavra com o tamanho do objeto. Outras indagaçóes surgiam: sem o domínio da linguagem escrita, como os sujeitos irâo utilizar o computador? O que conseguirâo fazer com um equipamento digital? Teria coordenaçăo motora para utilizar o teclado e o mouse? E para navegar na internet? Saberiam digitar antes mesmo de escrever? E depois de alfabetizadas, haverá muita diferença? Ainda náo éramos capazes de responder a essas perguntas, porem havia a certeza de que modelar um conjunto de testes adequado a recobrir o letramento digital poderia ser a chave para compreender e responder estas questôes.

\section{CRIANDO E OBSERVANDO OS EVENTOS DE LETRAMENTO DIGITAL}

O design do conjunto de testes desenvolvido foi inspirado nos questionários elaborados pelo governo francês que avaliavam o domínio de habilidades digitais entre crianças, jovens e adultos. Este instrumento de pesquisa compóem o brevê de 
informática e internet da França, que merece uma explanaçăo.

Em dezembro do ano 2000, o governo da França apresentou um documento, Brevet informatique et internet, ${ }^{148}$ cujo objetivo era especificar um conjunto significativo de competências no domínio da tecnologia da informaçâo e comunicaçáo e certificar a proficiência dos alunos (de escolas de ensino fundamental, médio, faculdades e escolar técnicas) em informática, com um diploma.

Para tanto, os testes ${ }^{149}$ foram elaborados para os três níveis de ensino: nível da escola, nível do colégio e nível da faculdade, tomando-se por base cinco áreas de habilidades comuns a esses níveis:

Dominar os fundamentos da tecnologia de computador (nomear hardware e software, usar o mouse e comandos de teclado elementares, abrir um arquivo existente, salvar um documento criado no diretório padrâo, abrir e fechar uma pasta);

Adotar uma atitude ética (verificar a pertinência e a precisâo dos dados, questionar a relevância e a validade dos dados, adotando uma abordagem crítica sobre as informaçóes, reconhecer e respeitar a propriedade intelectual);

Produzir, criar, modificar e operar um documento usando um software de processamento de texto - utilizar um documento existente, introduzir ou editar texto, formatá-lo de forma adequada, copiar, cortar, colar, manipular imagens, utilizar de forma fundamentada, o corretor ortográfico;

Usar produtos multimídia para pesquisa e/ou documentaçáo - realizar pesquisas na rede, utilizar a informaçâo recolhida - copiar e colar ou imprimir - comparar, escolher sabiamente os interesses da consulta sobre a mídia digital ou outros meios de comunicaçâo - enciclopédias, dicionários, livros de ficçăo, outros - pensar criticamente sobre os documentos, validar sua fonte;

Comunicar-se por meio de correio eletrônico - receber, imprimir, enviar, redirecionar e-mails, receber e usar um arquivo anexado - texto, imagem ou som - comparar o serviço prestado pela Internet a outros serviços de comunicaçăo (telefone, fax, e-mail).

Neste sentido, a metodologia que elaboramos foi inspirada neste conjunto de fatores que pertencem ao cenário digital, todavia náo poderíamos deixar de contextualizar, visto que o brevê francês foi desenhado para o ambiente francês e para outros sujeitos. Era necessário contextualizar tanto para a realidade brasileira quanto para a idade e momento da alfabetizaçâo dos sujeitos do nosso estudo.

Ainda, os interesses do brevê francês eram bem abrangentes, enquanto que os nossos eram mais específicos, voltados para a construçấo do letramento digital. No entanto, as habilidades abordadas no brevê francês nos iluminaram a respeito de quais habilidades săo pertinentes ao letramento digital, precisávamos elaborar este tópico.

148 Disponíveis em: <https://contrib.educnet.education.fr/textes/reGLEmentaires/competences/b2i/brevetinformatique-et-internet>; <http://www.education.gouv.fr/bo/2000/42/encart.htm〉. Acesso: 25 maio 2009.

149 Os testes que utilizamos como base referem-se ao Nível 1 e B2i, que era o mais elementar, já que nossos sujeitos são crianças bem pequenas. 


\section{DOMÍNIOS}

O letramento digital vem sendo comumente descrito e definido como um conjunto de habilidades técnicas, geralmente a partir de termos oriundos da língua inglesa, computer literacy, information literacy, e-literacy, network literacy e media literacy, entre as quais podemos destacar: letramento informacional, letramento computacional, letramento midiático, letramento multimidático. Anteriormente ao conceito de letramento digital, houve a expressăo alfabetizaçăo tecnológica (utilizada por Andrew Molnar, em 1972), que se referia ao aprendizado das técnicas de uso de aplicativos. Esta expressâo foi alterada por Frade (2005) para alfabetizaçâo digital. Esta mudança lexical ampliou o conceito, levando-o de aprendizado de técnicas para o uso de mídias digitais, de computadores, incluindo escrever e ler textos nesse novo suporte.

Cronologicamente, o conceito de letramento digital foi apresentado pela primeira vez por Paul Glister, em 1997, em seu livro com o mesmo título. Para este autor, o letramento digital nâo compreendia um conjunto de habilidades para utilizar o computador e sim "an ability to understand and to use information from a variety of digital sources" (BAWDEN, 2008, p. 18).

Knobel e Lankshear (2008) desenvolveram a partir do conceito proposto por Street (1984) para letramentos, estudos sobre os novos letramentos. Para estes autores, há duas interpretaçóes para o conceito de letramento digital. A primeira interpreta o fenômeno como parte de um conjunto de ideias, enfocado os aspectos cognitivos e sócio-emotivos envolvidos nas atividades em ambiente digital. E a segunda, como um conjunto de habilidades e técnicas específicas necessárias para qualificar o indivíduo como letrado digitalmente. Entre estes dois, a dupla norte-americana propóe que os letramentos digitais representam diversas formas de prática social, as quais emergiriam e se modificariam em novas práticas, podendo, inclusive, ser substituídas por outras.

Neste sentido, passamos a nos ocupar da elaboraçăo e descriçâo das habilidades linguístico-cognitivas envolvidas no processo de aquisiçâo e construçăo do letramento digital, tais como: a habilidade de nomear e identificar com léxico apropriado os equipamentos de informática, habilidade de realizaçăo de multitarefas, habilidades icônicas, entre outras. Ao conjunto dessas habilidades demos o nome de domínio. Entendemos que o termo domínio reflete bem a intençáo que tínhamos de demonstrar um conhecimento seguro e profundo a respeito das habilidades. Dessa maneira, o conjunto de habilidades linguístico-cognitivas para a construçăo do letramento digital ficou dividido em seis domínios, como apresentamos a seguir:

Domínio do ambiente de Informática: Reconhecimento dos equipamentos de informática e seu funcionamento;

Domínio das habilidades icônicas: Leitura de ícones e links de internet

Domínio do ambiente de conexáo: Como realizar a conexăo com a internet e navegar

Domínio da realizaçâo de múltiplas tarefas: Distribuir atençấo entre três mídias diferentes

Domínios da alfabetizaçâo e do letramento digital: Digitaçăo e uso de atalhos ou operadores do software 
Domínio da comunicaçăo na internet: Identificar e enviar novas mensagens

Entendemos que a divisâo em seis domínios exerce apenas uma funçâo didática, pois os testes e seus resultados entrelaçam estes conhecimentos, pois năo é possível conectar-se na internet sem reconhecer um ícone de navegador. Dessa forma, dividimos os domínios para organizarmos a metodologia e elaboraçăo dos testes, mas náo pretendíamos, com esta divisăo, compartimentalizar o conhecimento dos sujeitos e do letramento digital.

\section{A METODOLOGIA E OS DADOS}

Para estudar o letramento digital, buscamos além da produçăo com o próprio computador, as falas dos sujeitos, seus gestos, sua escrita e o desenho do seu contexto. Estas distintas materialidades dos dados remetem ao entendimento que temos de letramento digital como um fenômeno de natureza heterogênea, o que nos levou a recriar situaçôes onde o fenômeno se delineasse, contextualmente, visto que, sendo de natureza linguística, é irrepetível e dinâmico.

Como poderíamos emergir e delinear o fenômeno do letramento digital? Acreditávamos que a conjunçâo entre as atividades digitais com imagem e som e a navegaçăo na internet pode nos fornecer pistas dessa emergência, a partir das quais desenhamos o fenômeno. Os recortes dos dados compostos por imagens, falas, gestos, foram selecionados a partir dos quadros dos graus de letramento digital. A partir do exame derivado dos vídeos, da comparaçăo entre as naturezas diferentes das imagens, já que, por vezes, o dado de som captado pelo software CamStudio era mais limpo, nítido que aquele captado pela câmera externa, definimos os momentos mais representativos da configuraçáo do fenômeno do letramento digital.

A proposta de aplicar os testes estando as crianças isoladas da sala de aula, das condiçóes, implícitas ou năo, de uma avaliaçaáo perene, proporcionou um contexto de pesquisa mais livre, aberto à experimentaçăo, à tentativa, frustraçăo, sucesso e erro, nos quais os sujeitos por vezes se comportaram como navegadores errantes que, segundo Santaella (2004), mesmo desconhecendo o caminho, seguem princípios de adivinhaçăo.

Como lidávamos com crianças muito pequenas, ainda năo alfabetizadas no primeiro momento de captaçấo dos dados, pudemos perceber que, por vezes, o comportamento errante, pela falta de outros atributos como o sistema alfabético ou a familiaridade com os equipamentos de informática, assumia o papel de guia durante os testes no computador. Isto nos levou a caracterizar as crianças como típicas exploradoras, para quem, de acordo com Santaella (2004, p. 102), "sem começo, meio e fim claramente definidos, a navegaçăo é uma aventura".

\section{DESCRIÇĂO E ANÁLISE DOS DADOS}

Os dados que compóem essa metodologia săo:

Documento do processador de texto: obtido através da digitaçâo da criança, gravado em documento eletrônico do processador de texto e captado pelo software de som e imagem CamStudio; 
Imagens e dados orais: as imagens e os dados orais apresentam-se de duas fontes distintas, por meio de filmadora, que captava as imagens e os dados orais da criança realizando os testes, respondendo às perguntas, interagindo com o computador; e outra câmera, interna do próprio computador utilizado para a pesquisa, que captava tanto as imagens das açóes da criança durante os testes, quanto sua fala. Estas imagens, no caso, revelam o movimento do mouse, o clique com os botóes direito e esquerdo, que eram gravados com cores diferentes, a digitaçăo, o uso dos ícones da página de internet. Em geral, as sessóes de atividades com as crianças duravam de 10 a 20 minutos, com exceçâo para aquelas em que a conexăo era perdida, o que demandava um pouco mais de tempo para seu reestabelecimento.

Dados orais: além da filmagem que contém os dados orais, procedemos também à transcriçăo desses dados em forma de texto, para a melhor compreensăo de como se deram as interaçôes das crianças com o computador.

Questionário socioeconômico: os dados do questionário foram obtidos através de duas formas: entrevista presencial com os pais/responsáveis e pelo envio do questionário para a casa das crianças, feita pela escola, sobre equipamentos eletroeletrônicos que os sujeitos possuíam, além de hábitos como ir a lan house.

Entendendo que um trabalho de pesquisa com esta metodologia pode apresentar dados de naturezas diferentes, para a análise dos mesmos é recomendável que se proceda a um entrelaçamento entre o viés quantitativo e o qualitativo para a análise.

Como elegemos seis domínios do letramento digital, havia o risco de uma criança apresentar um perfil para cada domínio e repetir outros. Entretanto, a ideia de continuum nos confortava dessa angústia cartesiana, pois como o desenvolvimento do letramento digital, assim como da aprendizagem em geral, năo acontece em linha reta, e sim em movimentos de idas e vindas, por vezes entrelaçados. Acreditamos que as crianças poderiam fluir entres os perfis, alcançando melhores resultados em algumas tarefas e ainda se desenvolvendo em outras. Este continuum respeita a relaçăo entre escolaridade, idade e desenvolvimento das atividades da criança.

Detalhadamente, passamos a descriçâo das tarefas propostas nos testes desta metodologia.

\section{DOMÍNIOS E TESTES}

\section{a) Domínio do ambiente de Informática}

Lista de Equipamentos: Monitor, Teclado, Mouse, Caixas de som, Telefone Celular, Câmera Fotográfica digital, CPU, tablete, leitor eletrônico de livro, impressora.

Teste 1: O teste consiste em identificar os equipamentos de informática presentes no ambiente de pesquisa, perguntando à criança: "O que é isso? ", ao apontar para os itens. Entendemos que a construçâo do letramento digital perpassa o reconhecimento dos equipamentos que compóem um ambiente digital.

Teste 2: Funcionamento dos equipamentos de Informática. O teste solicita se os sujeitos sabem para que serve tal equipamento e se conseguem ligar e desligar um computador, por exemplo. 
Teste 3: Utilizaçáo do mouse. O teste avalia o domínio do uso do mouse entre os sujeitos, os diferentes cliques com o mouse, o uso dos dois botóes e a açấo de clicar e arrastar.

Teste 4: Utilizaçăo do teclado. O teste avalia o domínio do uso do teclado para os sujeitos, o que envolve a habilidade de digitaçăo e de utilizar teclas específicas como delete ou backspace para apagar (ou outra forma, como selecionar e apagar a palavra, clicando enter).

Teste 5: Registro de imagem estática. O teste avalia a habilidade de registrar imagens estáticas a partir dos dispositivos câmera fotográfica digital e telefone celular e como transferir os arquivos destes dispositivos para o computador.

\section{b) Domínio das habilidades icônicas}

Este domínio de testes busca captar a capacidade de percepçăo dos sujeitos no que se refere à iconicidade presente no ciberespaço, subdividido em dois grupos: capacidade de movimentaçăo no hipertexto e habilidades de percepçăo de ícones

Teste 6: Movimentar-se no hipertexto. O teste procura checar se os sujeitos conseguem navegar na página web utilizando a barra de rolagem e os ícones da página inicial, bem como se eram capazes de voltar e seguir um hiperlink.

Teste 7: Habilidades Icônicas. O teste avalia as habilidades icônicas das crianças ao navegarem no ciberespaço. Para tanto, observa-se se os sujeitos conseguem identificar ícones (Jogo, Vídeo e E-mail) em duas páginas específicas, uma baseada em linguagem icônica ${ }^{150}$ e outra mais baseada em linguagem verbal. Além de identificar também os ícones correspondentes a certas açōes (salvar, alterar fonte, tamanho da fonte, cor da fonte, colocar em negrito), em um processador de texto.

\section{c) Domínio do ambiente de conexăo}

Este domínio de testes avalia a habilidade de se conectar, conhecer e escolher um navegador de internet, acessar sites específicos no ciberespaço.

Teste 8: Gestos de conexăo. O teste avalia os conhecimentos sobre conexăo, além de avaliar os gestos que se executa para se conectar.

Teste 9: Navegadores e Navegaçâo. Este teste requer que os sujeitos, ao olharem para a tela do computador, que estava ligado e conectado à internet, respondam questôes como: "Olhando para essa tela, você sabe me dizer se este computador está conectado à internet?" Ou "Como entro na internet?". A ideia é identificar os mecanismos de conexâo e os navegadores. Este teste se baseia na hipótese de Palfrey e Gasser de que:

Os nativos digitais passam grande parte da vida online, sem distinguir entre o online ou offline. Em vez de pensarem na sua identidade digital e em sua identidade no espaço real como coisas separadas, eles têm apenas uma identidade (com representaçôes em dois, três ou mais espaços diferentes) (PALFREY; GASSER, 2011, p. 14).

150 Exemplo de página icônica disponível em: 〈http://www.smartkids.com.br〉; 〈http://discoverykidsbrasil. uol.com.br/?cc=BR>; 〈http://criancas.terra.com.br». 
Sendo assim, espera-se que as respostas às tarefas propostas correspondam a esta visăo de sujeito que constrói sua identidade em consonância com o digital.

\section{d) Domínio da realizaçăo de múltiplas tarefas}

Teste 10: Múltiplas tarefas. Este teste avalia uma das características dos seres digitais: a realizaçấo de múltiplas tarefas. Para tanto, propôe-se uma atividade que envolvia três mídias diferentes: um jogo, uma música e um desenho animado. Solicitase que os sujeitos joguem um jogo simples, (como o Jogo do Vestuário, ${ }^{151}$ disponível na internet), enquanto uma música toca (de preferência uma música bem conhecida), e visualiza-se, em outro monitor, um episódio de um conhecido desenho animado (como o Pica-Pau). ${ }^{152}$

Para a elaboraçăo desta atividade, tomamos como base os estudos dos autores holandeses Veen e Vrakking (2009). ${ }^{153}$ Eles elegeram a habilidade de realizar múltiplas tarefas como uma das características mais marcantes da nova geraçâo. Segundo estes autores, historicamente, as geraçóes anteriores aos seres digitais foram educadas de forma analógica, na qual era importante fazer uma coisa de cada vez para alcançar o sucesso. Já a nova geraçăo, educada de forma digital, consegue realizar suas tarefas ouvindo música, navegando na internet e zapeando a programaçăo da televisâo.

As atitudes nâo lineares das crianças da nova geraçăo, de acordo com os autores holandeses, "refletem sua capacidade de prestar atençăo a várias fontes de informaçáo ao mesmo tempo e com diferentes níveis de atençăo" (VEEN; VRAKKING, 2009, p. 58). De posse destas afirmaçóes, solicita-se que os sujeitos, entăo, completem ao mesmo tempo as três atividades. Após a execuçăo do jogo, procede-se a uma entrevista orientada sobre a atividade, com perguntas como: Você já conhecia esse jogo? Do que que era o jogo? O que que você fez no jogo? Você errou alguma vez? Era um menino ou uma menina? Que cor que era o chapéu dela? Você ouviu uma música? Você conhecia essa música? Do que falava a música, você sabe? Você viu que estava passando um desenho? Você conhece aquele desenho? Quem é? O que acontecia com o Pica-pau?

A entrevista tem por objetivo verificar: 1) a atençăo durante a atividade do jogo, sabendo, por exemplo, de que cor havia ficado o chapéu do personagem; 2) percepçâo da música; 3) percepçâo do desenho animado; 4) compartilhamento do saber. Assim, é possível avaliar se, de fato, os sujeitos conseguem executar múltiplas tarefas, distribuindo sua atençăo.

\section{e) Domínios da alfabetizaçăo e do letramento digital}

Teste 11: Utilizando o processador de texto. Com este domínio de testes, avalia-se o domínio da alfabetizaçăo e do letramento digital das crianças ao utilizar um processador de texto. Alfabetizaçáo porque conta com conhecimentos específicos da leitura e da escrita do sistema alfabético; e digital porque conta com conhecimentos a respeito

151 Disponível em: 〈http://www.smartkids.com.br/jogos-educativos/vestuario.html〉. Acesso em: 24 maio 2017.

152 Personagem criado em 1940 que até atualmente faz bastante sucesso entre as crianças.

153 Embora outros autores também tenham se dedicado a esta característica, como Fieldhouse e Nicholas (2008), Lankshear e Knobel (2008). 
do funcionamento de um documento de texto, que se comporta diferentemente de uma folha de papel e de conhecimentos de digitaçăo, que incluem conhecer o teclado, localizaçăo das letras, uso do mouse, formataçăo (fonte, tamanho, cor, entre outros).

Neste teste, várias tarefas săo solicitadas aos sujeitos: digitar o nome, aplicar diferentes estilos à palavra digitada, mudar a fonte, tamanho e cor, copiar e colar, apagar, imprimir e salvar parte ou todo o documento.

\section{f) Domínio da comunicaçâo na internet}

Teste 12: Utilizando mensagem instantânea a correio eletrônico. Utilizando-se aplicativos de mensagens instantâneas, ${ }^{154}$ a partir de uma situaçăo-problema, solicitase que os sujeitos enviem uma mensagem (ao colega de sala ou aos pais, dependendo da situaçăo), comunicando uma atividade da escola. A intençâo é avaliar se os sujeitos conseguem localizar um aplicativo de mensagem instantânea, localizar um contato, digitar a mensagem e enviar.

Pode-se repetir o mesmo procedimento para o correio eletrônico. Para isto, cria-se previamente uma conta de e-mail para fins de coleta de dados desse estudo. A partir dela, envia-se um e-mail aos sujeitos, com felicitaçôes e uso de emoticons, ${ }^{155}$ para que, de posse desse e-mail, possa se avaliar se os sujeitos sabem o que é: a caixa de entrada, os componentes do e-mail novo (data de envio da mensagem, remetente, corpo da mensagem), envio de novo e-mail (preenchimento dos campos).

Cabe salientar aqui que os testes ${ }^{156}$ que compóem essa metodologia sâo exemplos das possibilidades que podemos explorar frente à construçâo do letramento digital. É importante náo perder de vista a dinamicidade do processo de pesquisa, oportunizando-se se possível constante revisita aos conceitos fundadores metodologia para interpretar os dados a fim de explicitar tudo o que se considera necessário à execuçáo de uma investigaçấo com a máxima acuidade.

\section{CONSIDERAÇÕES FINAIS}

Este artigo pretendeu descrever uma metodologia de pesquisa para a investigaçấo da construçáo do letramento digital em crianças pequenas, ainda năo alfabetizadas formalmente. Para tanto, contou com apoio do referencial teórico dos estudos dos letramentos, inscritos no ideário da pós-modernidade. Para proceder com esta investigaçâo, elegeu-se seis domínios de habilidades linguístico-cognitivas, no interior das quais se manifesta o letramento digital, e elaborou-se doze testes que possibilitariam a emergência deste fenômeno.

154 Para este teste, é necessária instalaçăo prévia de aplicativos de mensagem instantânea (Whatsapp, Messenger, Telegram, Viber, Skype, Hangouts e um contato salvo) para a realizaçâo.

155 Uniăo dos termos emotion (emoçăo, em inglês) com icon (ícone, em inglês) para designar formas de comunicaçâo que se utiliza de caracteres tipográficos, tais como::), ou ^^^^e:-); ou imagem, para traduzir ou transmitir o estado emotivo ou psicológico dos participantes de uma interaçăo, geralmente em redes sociais de mensagens instantâneas, como o MSN.

156 Grande parte destes testes foi executada para a coleta de dados do estudo de doutoramento de Botelho, (2013). 
A metodologia aqui descrita năo encerra de maneira alguma as possibilidades de exploraçáo do letramento digital, e nem tem a intençăo de fazê-lo, até porque considera-se este tipo de letramento dentro da perspectiva do rizoma (DELEUZE; GUATARRI, 1999), cuja propriedade é a continuidade. Além disso, presenciamos um momento de intensa volatilidade de produtos, bens, relaçóes e modos de agir, o que se revela na forma de aprendizagem das novas geraçóes.

Esperamos que esta metodologia forneça subsídios teóricos e práticos para aqueles professores, pesquisadores e curiosos sobre o letramento digital e como as crianças aprendem o que aprendem atualmente frente aos dispositivos eletroeletrônicos e à internet. 


\section{REFERÊNCIAS}

BAWDEN, D. Origins and concepts of digital literacy.In: LANKSHEAR, Colin; KNOBEL, Michele. (Orgs.).Digital Literacies: concepts, policies and practices. New York: Peter Lang Publishing, 2008.

BAZERMAN, C. Escrita, gênero e interaçăo social. Săo Paulo: Cortez, 2007.

BOTELHO, F. G. A construçáo do letramento digital em crianças em fase de alfabetizaçăo. 2013. 292 f. Tese (Doutorado em Linguística) - Doutorado em Letras: Universidade Federal de Pernambuco, Recife, 2013.

BUZATO, M. Novos letramentos e apropriaçáo tecnológica: conciliando heterogeneidade, cidadania e inovaçấo em rede. In: RIBEIRO, Ana Elisa (Org.). Linguagem, tecnologia e educaçăo. Săo Paulo: Peirópolis, 2010.

FERREIRO, E.; TEBEROSKY, A. Psicogênese da Língua Escrita. Porto Alegre: Artmed, 1999.

FRADE, I. Alfabetizaçâo digital: problematizaçâo do conceito e possíveis relaçóes com a pedagogia e com aprendizagem inicial do sistema de escrita. In: COSCARELLI, Carla; RIBERIO, Ana Elisa. (Orgs.). Letramento digital: aspectos sociais e possibilidades pedagógicas. Belo Horizonte: Autêntica, 2005. 248 p.

GLISTER, P. Digital Literacy. New York: John Wiley \& Sons, 1997.

GOODY, J.; WATT, I. As consequências do letramento. Săo Paulo: Paulistana, 2006.

LANKSHEAR, C. e KNOBEL, M. Digital Literacies: concepts, policies and practices. New York: Peter Lang Publishing, 2008.

LEMOS, A., CUNHA, P. (Orgs.). Olhares sobre a Cibercultura. Sulina, Porto Alegre, 2003. LÉVY, P. Cibercultura. São Paulo: 34, 1999.

SANTAELLA, L. Navegar no ciberespaço. O perfil cognitivo do leitor imersivo. Sáo Paulo, Paulus, 2004.

STREET, B. Literacy in theory and practice. Cambridge: Cambridge University Press, 1999. (Publicada originalmente em 1984)

VEEN, W; VRAKKING, B. Homo ZappiensEducando na Era Digital. Porto Alegre: Artes Médicas, 2009.

XAVIER, A. C. Letramento digital: impactos das tecnologias na aprendizagem da Geraçâo Y. Calidoscópio, v. 9, n. 1, pp. 3-14, jan.-abr. 2011.

As Tecnologias e a aprendizagem (re)construcionista no Século XXI. Revista Hipertextus, v. 1, 2007. Disponível em: <http://www.hipertextus.net/volume1/artigo -xavier.pdf>. Acesso em: 24 fev. 2016. 